\title{
Canopy Management to Improve Grape Yield and Wine Quality - Principles and Practices*
}

\author{
R.E. Smart ${ }^{1}$, Joy K. Dick ${ }^{2}$, Isabella M. Gravett ${ }^{2}$ and B.M. Fisher ${ }^{3}$ \\ 1) Cassiro Pty. (Ltd.), RMB 67, Pacific Highway, Wauchope, New South Wales 2446, Australia \\ 2) MAF Ruakura Agricultural Centre, Private Bag, Hamilton, New Zealand \\ 3) DSIR Viticultural Research Station, Te Kauwhata, New Zealand \\ Submitted for publication: December 1989 \\ Accepted for publication: April 1990 \\ Key Words: Canopy management, solar radiation, shading, yield, wine quality
}

\begin{abstract}
This paper reviews the subject of canopy management with an attempt to develop principles. These principles provide guidelines for canopy surface area amount; spacing between canopies; within canopy shade, especially for the fruiting/renewal zone; balance between fruit and shoot growth; and uniformity of location of fruit/renewal zones, shoot tips and cane bases. Field techniques of point quadrat analysis and canopy scoring are introduced as an aid to defining problem canopies. These techniques are cheap, quick and effective. A set of twenty-one numeric indices and descriptors to assess winegrape canopies is then presented as a winegrape canopy ideotype, which can be further used as management guidelines. Recent publications are reviewed from various aspects of canopy management. These include vigour control, shoot trimming, leaf removal in the fruit zone and training system responses. The paper concludes with presentation of the authors' unpublished data on the effects of canopy microclimate on yield and wine quality. The trial was conducted with the cultivar Cabernet franc on a deep, fertile soil in a cool, high rainfall region. Canopy division using the Ruakura Twin Two Tier doubled yield compared to dense, vertical shoot positioned canopies which are common in New Zealand. Shade caused reduction in all yield components, and also delayed fruit ripening and reduced wine quality. Similar results were obtained by comparing fruit production at different heights with the Te Kauwhata Three Tier trellis system, where lower tiers were shaded at the canopy exterior. The results confirm that grape yield and wine quaity can be simultaneously increased by improved canopy management of shaded vineyards.
\end{abstract}

Canopy management is now an active area of research, especially in the New World winegrowing countries. It is generally accepted that Dr Nelson Shaulis of New York State pioneered canopy studies, especially with publication of the Geneva Double Curtain trellis (Shaulis et al., 1966). However, many of the principles that have emerged from recent research on canopy management are consistent with empirical observations and practices long since employed in Old World vineyards.

The adoption of technological advances, especially post World War Two has created a common situation of excessive vineyard vigour. This is particularly the case in the New World, where the benefits of improved soil preparation, irrigation, nutrition, fertilization and pest, disease and weed control practices have resulted in increased vigour. Further, there are many New World situations where vineyards have been planted on deep and fertile soils. The result of increased vine vigour is typically increased within-canopy shade. Recent research into canopy management has provided tech- niques to avoid shade.

This paper aims to condense existing knowledge by developing principles of canopy management. These principles are presented along with a series of quantitative indices which permit diagnosis of problem canopies. Field techniques to assess canopies are also presented in detail. The paper concludes with presentation of recent experimental evidence which further supports the principles proposed. This paper can be viewed as an extension of recent reviews on the same subject (Smart, 1985a; Smart 1987c).

\section{DEFINITIONS}

A Canopy, is defined as the leaf and shoot system of the vine (Shaulis \& Smart, 1974). It is described by dimensions of the boundaries in space (i.e. width, height, length etc), and also by the amount of shoot system within this volume (typically leaf area). Canopies are continuous where the foliage from adjacent vines down the row intermingle, and where there are no large gaps. If canopies are separated from vine to vine they are discontinuous. Where canopies of one vine (or

\footnotetext{
* Presented at the 13th congress of the SASEV, Cape Town, November 2, 1989.

Acknowledgements: The authors acknowledge assistance offield staff, especially Dave Thomsen and Maurice Roper at Rukuhia Horticultural Research Station for maintaining field experiments, and staff at Te Kauwhata Research Station for berry, must and wine analysis. Sensory data were generated by G. Kelly, B. Campbell, J. Babich, B. Marris, J. Healy, J. Hancock, M. Compton. Kay McMath helped arrange the tasting. David Jordan made helpful comments on the manuscript, and Glennis Steiner typed it. South African colleagues E. Archer, J. Steenkamp, J.J. Swanepoel, J.J. Hunter and J.M. Southey also made helpful suggestions on the manuscript.
} 
adjacent vines) are divided into discrete foliage walls the canopy is termed divided. Canopies are crowded or dense where there is much leaf area within the volume bounded by canopy surfaces - for example a high value of the ratio leaf area: canopy surface area (LA/SA, Smart, 1985a), or of leaf layer number (LLN, Smart, 1985a) or shoot density (shoots/m canopy, Smart, 1988).

The term canopy management includes a range of techniques which can be applied to a vineyard to alter the position or amount of leaves, shoots and fruit in space, and so as to achieve some desired arrangement (i.e. canopy microclimate). These techniques include winter and summer pruning, shoot positioning, leaf removal, shoot vigour control and use of improved training system. Canopy management techniques can be used to improve production and/or wine quality, reduce disease incidence, and facilitate mechanisation. Open canopies also lead to more efficient distribution of applied agricultural chemicals (Travis, 1987).

\section{CANOPY MICROCLIMATE}

Grapevine leaves as for other plants are strong absorbers of solar radiation, especially in the waveband $400-700 \mathrm{~nm}$ of photosynthetically active radiation (Smart, 1987a). Since only about $6 \%$ of light in this waveband is transmitted by a leaf (Smart, 1987b), light levels at the centre of dense canopies are very low, less often than $1 \%$ of above canopy values (Smart, 1985a).

With high yields, fruit may also cause shade. For example Palmer \& Jackson (1977) have quantified this effect for apple canopies. Similar results for grapevine canopies will be presented here. Light encountered in shade conditions has altered quality as well as quantity (Smart, 1987a; Smart, 1987b) with important physiological implications for leaves and fruit in shade conditions (Smart, 1987a). Studies to be detailed later have indicated that shade causes reductions in yield and quality. Therefore an aim of canopy management is to produce a canopy with minimal shade.

When the canopy microclimate is altered by canopy management techniques, it is not only sunlight levels that change. Temperature, humidity, wind speed and evaporation are also modified (Smart, 1985a). Altered evaporation rates are of significance to fungal disease incidence, (English et al., 1989), and exposure can alter thermal relations of grape berries with implications for their composition (Kliewer \& Lider, 1968; Smart \& Sinclair, 1976; Crippen \& Morrison 1986a, 1986b). However, the most significant feature of altered microclimate is for light quantity and quality levels within the canopy, from both a yield and fruit composition viewpoint (Champagnol, 1984; Smart, 1985a; Smart, 1987a).

Shade is avoided by reducing leaf area and increasing the proportion of canopy gaps (Smart, 1988). However, too high a proportion of canopy gaps allows sunlight to be 'lost', falling on the vineyard floor. What is required is a balance between excessive gaps (and hence waste of sunlight energy) and insufficient gaps (and the creation of shade).

\section{PRINCIPLES OF CANOPY MANAGEMENT}

Listing of principles: Five principles will be briefly stated and justified by literature reference. Recent results are presented at the end of the paper to further support the first four of these principles.

Principle 1. A large canopy surface area well exposed to sunlight is desirable, and this surface area should develop as quickly as possible in spring: Sunlight interception is increased (Smart, 1973), and canopy density reduced (Shaulis \& Smart, 1974; Smart, 1985a) with large exposed canopy surface area. Biomass production and yield potential is increased as more solar energy is trapped by foliage. Rapid development of canopy surface area in spring promotes solar energy interception. Clingeleffer (1989) argues that rapid canopy development is part of the reason for increased yield of minimal pruned vines. Tall, thin, relatively closely spaced, vertical, north-south foliage walls provide maximum exposure for a canopy surface (Smart, 1973; Jackson \& Palmer, 1972). Note however that very high values of canopy surface area are not possible without violating principle 2. Overhead canopies, and wide row, low vigour vineyards have low values.

Principle 2. Canopies should not be so close together as to cause excessive shade at the base of adjacent canopies. Vertical canopies are preferred and the ratio of canopy height to alley width should not exceed about 1:1: Where canopies are close together penetration of both direct and diffused sunlight into the enclosure formed by canopy walls and the ground surface is impaired, as is demonstrated by calculation (Jackson \& Palmer, 1972; Smart, 1973) and by field measurement (Smart, 1985b; Intrieri, 1987). Photosynthesis is inhibited for exterior leaves at the base of closelyspaced canopies. Figure 1 shows calculated values of sunlight flux densities over summer down the side of vertical canopy

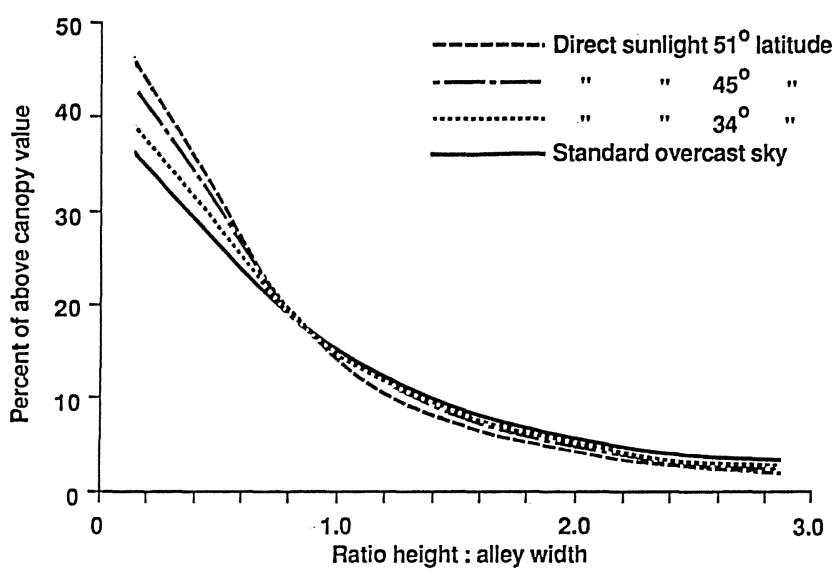

FIGURE 1

Solar radiation flux density estimated at various positions down the vertical walls of canopies, expressed as a percentage of that received by a horizontal surface above the canopy. Position on the wall indicated by the ratio of canopy height: alley width. Data are for seven summer months, direct sunlight on north south walls, $34^{\circ}, 45^{\circ}$ and $51^{\circ}$ latitude, and standard overcast sky (data from Jackson \& Palmer, 1972). 
walls for direct sunlight (north-south rows) at $34^{\circ}, 45^{\circ}$ and $51^{\circ}$ latitude and for a standard overcast sky (from Jackson \& Palmer, 1972). Note the similarity between all curves, and that values corresponding to height: alley width ratio of $1: 1$ are about $15 \%$ of above canopy values.

Principle 3. Canopy shade should be avoided, especially for the cluster/renewal zone. Leaves and fruit should have as uniform a microclimate as possible: Adequate fruit exposure to sunlight promotes wine quality, though effects of leaf and fruit exposure are not often separated experimentally. Shaded canopies produce fruit of increased $\mathrm{K}, \mathrm{pH}$, malic acid and Botrytis bunch rot incidence, and reduced sugar, tartaric acid, phenol and anthocyanin levels (reviewed by Smart, 1985a; Shaulis, 1982; Smart et al., 1988; Kliewer \& Smart, 1988; Kliewer et al., 1988). Morrison (1988) has shown that leaf shading affects berry size, sugar, $\mathrm{K}$ and $\mathrm{pH}$ while cluster shading lowers fruit anthocyanin levels and phenols. Shading reduces fruit monoterpenes (Reynolds \& Wardle, 1988, 1989a, 1989c) and induces herbaceous characters in wine (Pszczolkowski et al., 1985). Also, Carbonneau et al. (1978) note that excessive fruit exposure may increase phenol concentrations beyond desirable levels. It is likely that high quality wine results from processing fruit of relatively homogeneous composition. Preliminary studies indicate that shaded fruit shows more variation in composition (S. Smith, unpublished data). Since fruit composition responses to microclimate are already evident by veraison (Smart, 1982), it is likely that pre-veraison canopy microclimate has a significant impact on wine quality. Botrytis incidence is increased by high canopy density as fruit exposure is reduced (Gubler et al., 1987; Savage \& Sall, 1984). Similar effects of shading are noted for Oidium incidence (Pearson \& Goheen, 1988). Improved spray penetration also assists disease control (Travis, 1987).

The light microclimate of the renewal zone (base of the shoot which is retained at winter pruning) is important for yield expression (Shaulis 1982; Shaulis \& Smart, 1974). Located in this zone are the nodes retained at winter pruning, as well as grape clusters. Shading of this zone causes reduced cluster initiation, bud break, fruit set and berry size (Shaulis \& Smart, 1974; Shaulis, 1982; Smart et al., 1982b). Basal leaves are also known to be important for fruit ripening processes (Hunter \& Visser, 1988). The effect of shade on fruit set is little studied but poor fruit set in the centre of dense canopies is commonly observed. Recently Jackson \& Coombe (1988) suggested this could be due to a physiological disorder Early Bunch Stem Necrosis (EBSN). Shade leaves contribute little to canopy photosynthesis (Smart, 1974; Smart, 1985b) and in time turn yellow and abscise.

Principle 4. Photosynthate partitioning between shoot and fruit growth should be appropriate to avoid either excess or deficient leaf area relative to the weight of fruit. The number of active vegetative growing points per shoot should be limited: Grapevine shoots are potentially indeterminate, and excessively large shoots are a common feature of vigorous vineyards. Vigorous shoots have relatively large diameter, long internodes and large leaves, and there is a marked propensity for active lateral growth; such features are undesirable and indicate an imbalance between vegetative and fruit growth (Smart et al., 1989). Vineyards of high yield demonstrate a balance between shoot and fruit production (e.g. Lavee \& Haskal, 1982), an indication that photosynthate is partitioned appropriately between shoot and fruit production. Shoot devigoration can be achieved by a combination of light pruning and improved canopy microclimate, the socalled 'big vine' effect (Smart et al., 1989). Long shoots represent photosynthate diversion into superfluous leaf area, which in turn generally contributes to canopy shading. Long shoots cause high must and wine $\mathrm{pH}$ (Smart, 1982). Partial defoliation improves photosynthetic efficiency of remaining leaves (Hunter \& Visser, 1988). Shoots that are too short may have insufficient leaf area to adequately ripen fruit (i.e. Peterson \& Smart, 1975; Koblet, 1987a). Shoot growth may be regulated by summer trimming (Reynolds \& Wardle, 1989b), though for vigorous shoots the lateral buds near the shoot apex burst and continue extension growth (Solari et al., 1988). The balance between shoot and fruit production can be assessed by the ratio yield: pruning mass, sometimes termed 'crop load'. Bravdo et al. (1985) found in Israel that values of this ratio greater than 10 with Cabernet Sauvignon led to reduced quality, with no quality effect for values less than 10. Studies by Reynolds (1989) with Riesling in cooler British Columbia found values less than 10 desirable.

There have been few studies of shoot length heterogeneity and its effect, though it is likely that uniform populations are desirable (Smart et al., 1989).

Principle 5. Arranging locations of individual organs in restricted zones in space facilitates mechanisation i.e. of shoot tips for summer pruning, of cane bases for winter pruning and of fruit for mechanical harvesting. Training system design should as much as possible create fruiting/renewal zones at a similar height for any one vine: For vines trained with renewal zones at various heights, the highest buds burst preferentially before those of lower vine parts. This effect is presumably gravimorphic though in many situations low renewal zones are also shaded, which effect reduces bud break. Thus Van den Ende (1984) found most of the fruit production of Sultana vines on the Tatura trellis was at the top of the canopy after a few years cropping, though originally vines had replacement zones at six heights.

\section{DIAGNOSIS OF PROBLEM CANOPIES}

This section comprises two parts. The first presents in detail field methods for evaluating winegrape canopies. In the second, quantitaive indices are presented as guidelines to canopy assessment.

The techniques we have developed for diagnosing problem canopies are designed for practical field use by researchers and growers. The techniques are easy to learn and interpret, quick to use and also inexpensive.

Point quadrat: This technique was first applied to vineyard canopy studies in 1980 (Smart, 1982) though the presentation of results is now modified. This simple method describes the distribution of leaves and fruit in space, and provides quantitative canopy description. A sharpened thin metal rod is passed at fixed inclination into the canopy (normally in the fruit zone) and contacts with leaves, clusters and 
TABLE 1

Sample point quadrat analysis sheet for two contrasting canopies (ex Smart \& Sharp, 1989).

Key: $\mathrm{L}=$ Leaf contact $\quad \mathrm{C}=$ Cluster contact $\quad \mathrm{G}=$ Canopy gap

\begin{tabular}{|c|c|c|c|c|c|c|c|c|c|c|c|c|c|c|c|}
\hline \multicolumn{8}{|c|}{$\begin{array}{l}\text { Low density canopy } \\
\text { Cabernet franc, TR2T }\end{array}$} & \multicolumn{8}{|c|}{$\begin{array}{l}\text { High density canopy } \\
\text { Gewürztraminer, standard }\end{array}$} \\
\hline 1 & $\mathrm{~L}$ & 13 & LC & 26 & LCC & 39 & $\mathrm{C}$ & 1 & LLCCL & 13 & LLL & 26 & LLLLL & 39 & LCCCCLL \\
\hline 2 & LLC & 14 & $\mathrm{CL}$ & 27 & LCL & 40 & $\mathrm{G}$ & 2 & LLL & 14 & LCLCL & 27 & LLLLLL & 40 & CLL \\
\hline 3 & LLC & 15 & $\mathrm{~L}$ & 28 & $\mathrm{G}$ & 41 & $\mathrm{C}$ & 3 & LL & 15 & LLLL & 28 & LLLLLCLL & 41 & LC \\
\hline 4 & $\mathrm{LC}$ & 16 & $\mathrm{~L}$ & 29 & $\mathrm{G}$ & 42 & CLCC & 4 & $\overline{\mathrm{LL}}$ & 16 & LLL & 29 & LLLLL & 42 & CCLLL \\
\hline 5 & $\mathrm{~L}$ & 17 & $\mathrm{CL}$ & 30 & $\mathrm{~L}$ & 43 & $\mathrm{G}$ & 5 & LLCL & 17 & LLL & 30 & LLLL & 43 & LLL \\
\hline 6 & $\mathrm{~L}$ & 18 & LL & 31 & $\mathrm{C}$ & 44 & $\mathrm{CC}$ & 6 & LLCLLL & 18 & LL & 31 & $\mathrm{LL}$ & 44 & LLCLL \\
\hline 7 & LCL & 19 & $\mathrm{~L}$ & 32 & LL & 45 & $\mathrm{C}$ & 7 & LLCL & 19 & LCL & 32 & LLCCLL & 45 & LLCLL \\
\hline 8 & G & 20 & $\mathrm{~L}$ & 33 & $\mathrm{G}$ & 46 & LC & 8 & CLLL & 20 & LLLL & 33 & LCLL & 46 & LLCCL \\
\hline 9 & G & 21 & $\mathrm{~L}$ & 34 & $\mathrm{G}$ & 47 & $\mathrm{G}$ & 9 & LCLL & 21 & LCLLLL & 34 & LLL & 47 & LLCCL \\
\hline 10 & LLC & 22 & $\mathrm{~L}$ & 35 & LCL & 48 & $\mathrm{G}$ & 10 & $\mathrm{LL}$ & 22 & LLL & 35 & LCCLL & 48 & LLLCL \\
\hline 11 & G & 23 & $\mathrm{~L}$ & 36 & LLL & 49 & $\mathrm{~L}$ & 11 & LL & 23 & LLL & 36 & LL & 49 & LLLCLLLL \\
\hline 12 & $\mathrm{~L}$ & 24 & $\mathrm{G}$ & 37 & LL & 50 & LL & 12 & LLL & 24 & CLL & 37 & LLLLLLC & 50 & LLCLCL \\
\hline & & 25 & $\mathrm{G}$ & 38 & $\mathrm{~L}$ & & & & & 25 & LCC & 38 & LCLL & & \\
\hline
\end{tabular}

Percent gaps:

LLN:

Percent interior leaves:

Percent interior clusters:
$13 / 50=26 \%$

$43 / 50=0,86$

$4 / 43=9 \%$

$6 / 23=26 \%$
$0 / 50=0 \%$

$167 / 50=3,34$

$72 / 167=43 \%$

$36 / 39=92 \%$ canopy gaps noted. Stems are normally ignored. Each insertion takes about 10 seconds. Typically 50-100 passes are made for each canopy to be analysed. The following canopy descriptors can be generated from the data - percent gaps, LLN (leaf layer number), percent interior leaves and percent interior clusters (Smart \& Smith, 1988; Smart \& Sharp, 1989). Table 1 shows typical data for high and low density canopies, and demonstrates the method to calculate canopy density indices.

Vineyard scoring: The concept of visual canopy assessment to predict winegrape quality was first described by Smart et al., (1985a). Canopy assessment takes place between veraison and harvest using eight characters as presently proposed (Smart \& Smith, 1988; Smart \& Sharp, 1989). Three of these characters describe microclimate (canopy gaps, canopy density and fruit exposure) and five describe prior growth or physiological status (Table 2). Each character is assessed out of 10 points, giving a total of 80 . Note that the scorecard should not be used for diseased, unhealthy or excessively stressed vines.

The scorecard as presented is based on observation and measurement of high quality vineyards in Australia, New Zealand, USA, France and Germany. In particular, detailed s.udies of Cabernet Sauvignon vineyards in the Graves region of France were most instructive (Smart, Carbonneau $\&$ de Loth, unpublished). Development of the scorecard was supported by extensive vineyard microclimate measurements (Smart, 1982; Smart et al., 1982a; Smart et al., 1985a; Smart et al., 1985b; Smart 1987b; Smart 1988; Smart \& Smith, 1988). For all of this, some arbitrariness is recognised in the scorecard construction. For example it is difficult to justify only eight characters, and that they should all have equal weighting. The scorecard is suggested as first approximation only, and modification to accommodate different cul- tivars in different regions is encouraged. For Mediterranean climates, the addition of a descriptor for vine water status is considered desirable.

Scoring a canopy takes less than two minutes. Results are presented here to illustrate that little judge training is required. In February 1987 we compared the scores from four judges. Judge A had five years experience with the scorecard, judge $B$ had two years experience, and judges $C$ and $D$ were using the scorecard for the first time. Thirty experimental plots of Cabernet franc were assessed, comprising two rootstocks by five training systems with three replicates. The four judges initially discussed scores for several canopies, then worked separately. Results were analysed to investigate "judge" effects for each character scored.

Analysis of variance showed that trellis treatment was the variable with most significance ( 8 out of 9 ), followed by judge effects ( 7 out of 9 ), and no rootstock effect. Interaction of judge (with rootstock or trellis) was less frequent, occurring 6 times out of a possible 27. Treatment effects were of less significance or no significance where the range in scores was small i.e. for the characters shoot length and presence of growing tips. Similarly, these same characters correlated poorly when other judges scores were correlated with judge $\mathrm{A}$, and the character fruit exposure had the highest correlation coefficient. There was little apparent effect of prior judge experience. The limited frequency of interactions with judges supports the contention of using several judges and averaging their scores.

Vine growth and yield measurements: Simple measurements at winter pruning of cane number and retained node number and total cane mass, and of yield and bunch number at harvest allows useful indices of vine balance to be determined. There are: 
TABLE 2

Vineyard scorecard for assessing vineyard potential to produce quality winegrapes.

NOTE: If majority of shoots are less than $30 \mathrm{~cm}$ long, or if these vines are clearly diseased or chlorotic or necrotic, or excessively stressed, DO NOT SCORE VINEYARD.

A. Standing away from canopy

1 CANOPY GAPS (from side to side of canopy, within area contained by $90 \%$ of canopy boundary)

*about $40 \%$

*about $50 \%$ or more

*about $30 \%$

*about $20 \%$

*about $10 \%$ or less

2 LEAF SIZE (basal-mid leaves on shoot, exterior).

For this variety are the leaves relatively:

*slightly small

*average

*slightly large

*very large

*very small

3 LEAF COLOUR (basal leaves in fruit zone) *leaves green, healthy, slightly dull and pale

*leaves dark green, shiny, healthy

*leaves yellowish green, healthy

*leaves with mild nutrient deficiency symptoms

*unhealthy leaves, with marked necrosis or chlorosis 2

B. Standing at Canopy

4 CANOPY DENSITY (from side to side in fruit zone), mean leaf layer number

*about 1 or less

*about 1,5

*about 2

*more than 2
$5 \quad$ FRUIT EXPOSURE (remember that the canopy has two sides normally - that fruit which is not exposed on your side may be exposed to the other side)

*about $60 \%$ or more exposed 10

*about $50 \%$

*about $40 \%$

*about $30 \%$

*about $20 \%$ or less

6 SHOOT LENGTH

*about 10-20 nodes 10

* about 8-10 nodes 6

* about 20-25 nodes 6

* less than about 8 nodes 2

* more than about 25 nodes 2

7 LATERAL GROWTH (normally from about point where shoots trimmed. If laterals have been trimmed, look at diameter of stubs)

* limited or zero lateral growth 10

* moderate vigour lateral growth 6

* very vigorous growth 2

8 GROWING TIPS (of all shoots, the proportion with actively growing tips - make due allowance for trimming)

* about $5 \%$ or less $\quad 10$

* about $10 \%$

* about $20 \% \quad 6$

* about $30 \%$

* about $40 \% \quad 4$

* about $50 \%$ or more 0

Total point score $\quad \quad \quad / 80=$

TABLE 3

Summary of anova results with four judges of differing experience.

\begin{tabular}{|c|c|c|c|c|c|c|c|c|c|c|}
\hline \multirow[t]{2}{*}{$\begin{array}{l}\text { Character } \\
\text { assessed }\end{array}$} & \multirow[t]{2}{*}{$\begin{array}{l}\text { Range } \\
\text { of values } \mathrm{s}^{\mathrm{a}}\end{array}$} & \multirow{2}{*}{$\begin{array}{c}\text { Rootstock } \\
\mathrm{R}\end{array}$} & \multirow{2}{*}{$\begin{array}{c}\text { Trellis } \\
\mathrm{T}\end{array}$} & \multirow{2}{*}{$\begin{array}{c}\text { Significance } \\
\text { Judge } \\
\text { J }\end{array}$} & \multirow[t]{2}{*}{ RXJ } & \multirow[t]{2}{*}{ TXJ } & \multirow[t]{2}{*}{ RXTXJ } & \multicolumn{3}{|c|}{$\begin{array}{c}\text { Correlation with Judge } A^{c} \\
\text { Judge }\end{array}$} \\
\hline & & & & & & & & B & $\mathrm{C}$ & D \\
\hline Canopy gaps & $0,6-9,2$ & - & $* * * b$ & * & & & & 66 &, 78 &, 79 \\
\hline Leaf size & 7,3-9,7 & - & *** & ** & & & & ,43 & ,67 & ,67 \\
\hline Leaf colour & $7,1-9,8$ & - & $* * *$ & *** & & ** & & ,33 & ,60 & ,67 \\
\hline Canopy density & $2,2-8,5$ & - & $* * *$ & $* * *$ & * & $* * *$ & $* *$ & 64 &, 71 & ,62 \\
\hline Fruit exposure & $2,8-10,0$ & - & $* * *$ & - & & $* * *$ & & ,94 & 83 & ,97 \\
\hline Shoot length & 9,6-10,0 & - & * & - & & & &,- 11 &,- 14 &, 07 \\
\hline Lateral growth & $5,7-9,8$ & - & $* * *$ & $* * *$ & & & & 69 & ,62 &, 71 \\
\hline Growing tips & $9,9-10,0$ & - & - & * & & & & 0 & 0 & 0 \\
\hline Total & $46-76$ & - & $* * *$ & $* * *$ & & * & & ,91 &, 86 & ,93 \\
\hline
\end{tabular}

${ }^{a}$ highest and lowest mean score for trellis treatments, an indication of data spread.

$\begin{array}{lll}{ }^{\mathrm{b}} \text { significance level } & * \mathrm{P}<, 05 \\ & * * \mathrm{P}<, 01 \\ & * * * \mathrm{P}<, 001 \\ \mathrm{c} \text { correlation coefficients } & \mathrm{r}>0,35 & \mathrm{P}<, 05 \\ & \mathrm{r}>0,45 & \mathrm{P}<, 01 \\ & \mathrm{r}>0,56 \quad \mathrm{P}<, 001\end{array}$


- average cane mass (total cane mass/cane number) with high values indicating excessive vigour,

- total cane mass $(\mathrm{kg} / \mathrm{m}$ row or per m canopy) with high value indicating high canopy density,

- yield/cane mass ratio, with low values indicating imbalance due to excessive vigour (Bravdo et al, 1984),

- bud burst (shoots per node) and fruitfulness (clusters/shoot) with low values indicating among other things effects of shaded canopies.

Other measurements: Light microclimate may be measured with electronic sensors, with due caution exercised for sampling problems. Similarly leaf area may be determined and the vigour index $\gamma$ calculated (see Smart, 1985a) as well as the leaf area/crop mass ratio. However both of these techniques are considered more complex than is required for most practical vineyard assessment situations (Smart \& Sharp, 1989).

\section{PROPOSING A WINEGRAPE CANOPY IDEOTYPE}

Following on the ideotype concept of Donald (1968) for an ideal wheat plant description, we now present a grapevine canopy ideotype. The ideotype proposed is a series of numeric indices and characters which can be used to assess winegrape canopies. The values presented are believed optimal for winegrape yield and quality with current knowledge, but may be found to require modification for different cultivars or environments. These values should be especially useful as guidelines for canopy management in high vigour situations. Some of the indices presented have not been previously introduced and references from the literature that support the values are included.

Of the indices listed in Table 4, we have found the following to be the most useful for vineyard diagnosis and trellis evaluation; surface area, shoot spacing, shoot length, lateral development, ratios of yield: canopy surface area and yield to pruning mass, and LLN.

\section{YIELD AND QUALITY RESPONSES TO CANOPY MANAGEMENT}

This section will briefly review published responses to canopy management techniques, and the next Section will present data for trellis system effects on yield and quality. It should be emphasised that a range of canopy management techniques are available, and the suitability of various techniques depends on vineyard vigour, when considerations of economics and practicability are not considered. As a general principle, the desirability of adoption of a more complex training system is increased as vineyard vigour increases. For low to moderate vigour vineyards, summer trimming (hedging) or fruit zone leaf removal may be sufficient to improve microclimate.

Vigour control: Low shoot vigour helps create open canopies. Examples of this are given by Smart (1985a) and Smart et al., (1989) who reviewed management techniques to achieve devigoration.

Shoot trimming: Unless shoot growth is inhibited, for example, by water stress (Smart \& Coombe, 1983) or by light pruning (Clingeleffer, 1989; Smart et al., 1989) shoot growth normally continues beyond optimum length. Summer trimming (hedging) to contain shoot growth is widely used in high humidity environments like Europe and New Zealand, but less frequently in drier climates like Australia and California. As long as trimming is done early, fruit ripening is encouraged (Solari et al., 1988; Koblet, 1987a; Koblet, 1988). Kliewer \& Bledsoe (1987) have however found that trimming delayed fruit maturity. Perhaps this result was due to removing exterior, photosynthetically active leaf area and exposing less efficient leaves.

Leaf removal in the fruit zone: Fruit exposure in dense canopies can be enhanced by preveraison leaf removal in the cluster zone. Fruit composition is improved and herbaceous wine characters reduced (Kliewer and Bledsoe, 1987; Smith et al., 1988; Freese, 1988; Kliewer et al., 1988; Iland, 1988). Leaf removal also facilitates control of Botrytis bunch rot (Gubler et al., 1987; Smith et al., 1988).

Training system: The pioneering studies of Shaulis et al (1966) demonstrated that within canopy shade was a principle cause for yield and quality reductions, and that this could be overcome by canopy division. Subsequently, a large number of studies with a range of cultivars and environments have confirmed the same principles. Smart (1985a) reviewed earlier work and to this list can now be added Carbonneau (1985), Carbonneau \& Casteran (1987), Casteran \& Carbonneau (1987), Intrieri (1987), Cullen (1988), Kliewer et al., (1988), and Smart \& Smith (1988). More complex training systems typically have more old wood per vine as trunks and cordons, and this also enhances yield (Murisier \& Spring, 1987; Koblet, 1987b). The ability of canopy division to improve vine microclimate and performance is dependant on vineyard vigour. This was emphasised by Smart et al. (1985a), Smart et al. (1985b), Carbonneau \& Casteran (1987a), and Casteran \& Carbonneau (1987).

\section{RECENT RESULTS FROM CANOPY MANAGEMENT EXPERIMENTS}

The paper concludes by presenting recent experimental results from a trellis trail which support principles developed above. Results presented will be limited to three of the five treatments, and to two seasons. The full results of the trial will be the subject of a further report.

A trail with the cultivar Cabernet franc was established in 1983 at Rukuhia, near Hamilton to investigate yield and quality responses to training systems. The soil is deep and fertile (Horotiu silt loam, $80 \mathrm{~cm}$ of silt loam over coarse sand and gravel extending for several meters). The climate can be described using the Smart-Dry index (Smart \& Dry, 1980) as cool $(\mathrm{MJT}=17,3 \mathrm{C})$, maritime $(\mathrm{CTL}=9,2 \mathrm{C})$, overcast $(\mathrm{SSH}$ $=6,5 \mathrm{hrs} /$ day), not arid (deficit $60 \mathrm{~mm}$ ), and very humid $(\mathrm{RH}$ $=73 \%)$. Such conditions are favourable to high vine vigour and restrict maturity for this late season cultivar. The trial compares five training systems and two rootstocks (1202 Couderc (1202C) and Aramon Rupestris Ganzin 1 (ARGI)). There are three replicates, each plot consisting of six vines. Generally, rootstocks have only small effects and these are not discussed here. The training systems are Te Kauwhata Three Tier (TK3T) and Te Kauwhata Two Tier (TK2T) at row spacing $1,8 \mathrm{~m}$, and Tatura trellis, Ruakura Twin Two Tier 
TABLE 4

Winegrape canopy ideotype to promote high yields and improved fruit composition.

\begin{tabular}{|c|c|c|}
\hline Character assessed & Optimal Value & Justification of optimal value \\
\hline \multicolumn{3}{|l|}{ Canopy characters: } \\
\hline Row orientation & north-south & $\begin{array}{l}\text { Promotes radiation interception Smart (1973) though Champagnol (1984) argues that } \\
\text { hourly interception should be integrated with other environmental conditions i.e. temper- } \\
\text { atures which affect photosynthesis to evaluate optimal row orientation for a site. Wind } \\
\text { effects can also be important (Weiss \& Allen, 1976a; Weiss \& Allen, 1976b). }\end{array}$ \\
\hline Ratio canopy height: alley width & $\sim 1: 1$ & $\begin{array}{l}\text { High values lead to shading at canopy bases, and low values lead to inefficiency of radia- } \\
\text { tion interception. (See literature cited for Principle } 2 \text {; data in this paper.) }\end{array}$ \\
\hline Foliage walls inclination & vertical or nearly so & Underside of inclined canopies is shaded (Smart \& Smith, 1988). \\
\hline Renewal/Fruiting area location & near canopy top & $\begin{array}{l}\text { A well exposed renewal/fruiting area promotes yield and, generally, wine quality, al- } \\
\text { though phenols may be increased above desirable levels. (See literature cited for princi- } \\
\text { ple 3; data in this paper.) }\end{array}$ \\
\hline Canopy surface area (SA) & $\sim 21,000 \mathrm{~m}^{2} / \mathrm{ha}$ & $\begin{array}{l}\text { Lower values generally indicate incomplete sunlight interception, higher values are asso- } \\
\text { ciated with excessive cross row shading. (See literature cited for principle } 1 \text {; data in this } \\
\text { paper.) }\end{array}$ \\
\hline Ratio leaf area/surface area (LA/SA) & $<1,5$ & $\begin{array}{l}\text { An indication of low canopy density especially useful for vertical canopy walls. (Smart } \\
\text { 1982; Smart et al, 1985a and literature cited for principle 3). }\end{array}$ \\
\hline Shoot spacing & $\sim 15$ shoots $/ \mathrm{m}$ & $\begin{array}{l}\text { Lower values associated with incomplete sunlight interception, higher values with } \\
\text { shade. Optimal value is for vertical shoot orientation and varies with vigour (Smart, } \\
\text { 1988). }\end{array}$ \\
\hline Canopy width & $300-400 \mathrm{~mm}$ & $\begin{array}{l}\text { Canopies should be as thin as possible. Values quoted are minimum likely width. Actual } \\
\text { value will depend on petiole and lamina lengths and orientation. }\end{array}$ \\
\hline \multicolumn{3}{|l|}{ Shoot and fruit characters: } \\
\hline Shoot length & $\begin{array}{l}10-15 \text { nodes, about } 600- \\
900 \mathrm{~mm} \text { length }\end{array}$ & $\begin{array}{l}\text { These values are normally attained by shoot trimming. Short shoots have insufficient } \\
\text { leaf area to ripen fruit; long shoots contribute to canopy shade and cause elevated must } \\
\text { and wine } \mathrm{pH} \text { (see literature cited for principle } 4 \text { ). }\end{array}$ \\
\hline Lateral development & $\begin{array}{l}\text { limited, say less than } 5- \\
10 \text { lateral nodes total } \\
\text { per shoot }\end{array}$ & $\begin{array}{l}\text { Excessive lateral growth is associated, with high vigour (Smart et.al., 1985a; Smart \& } \\
\text { Smith, 1988; Smart, 1988, Smart } \text { et al., 1989). }\end{array}$ \\
\hline Ratio yield: canopy surface area & $\begin{array}{l}1-1,5 \mathrm{~kg} \text { fruit } / \mathrm{m}^{2} \mathrm{can}- \\
\text { opy surface }\end{array}$ & $\begin{array}{l}\text { This is value of exposed canopy surface area required to ripen grapes (Shaulis \& Smart, } \\
\text { 1974). Values of } 2,0 \mathrm{~kg} / \mathrm{m}^{2} \text { have been found to be associated with ripening delays in } \\
\text { New Zealand, but higher values may be possible in warmer and more sunny climates. }\end{array}$ \\
\hline Ratio yield: total cane mass & $6-10$ & $\begin{array}{l}\text { Low values associated with low yields and excessive shoot vigour. Higher values associ- } \\
\text { ated with ripening delays and quality reduction. (See literature cited for principle } 4 \text {.) }\end{array}$ \\
\hline Growing tip presence after veraison & nil & $\begin{array}{l}\text { Encourages fruit ripening since actively growing shoot tips are an important alternate } \\
\text { sink to the cluster (Koblet, 1987a). }\end{array}$ \\
\hline Cane mass (g) (in winter) & $20-40 \mathrm{~g}$ & $\begin{array}{l}\text { Indicates desirable vigour level. Leaf area is related to cane mass, with } 50-100 \mathrm{~cm}^{2} \text { leaf } \\
\text { area/g cane mass. Values will vary with variety, shoot length (Smart \& Smith, 1988; } \\
\text { Smart } \text { et al., 1989; also data in this paper). }\end{array}$ \\
\hline Internode length & $60-80 \mathrm{~mm}$ & Indicates desirable vigour level (Smart et al, 1989). Values will vary with variety. \\
\hline Total cane mass: m canopy length & $0,3-0,6 \mathrm{~kg} / \mathrm{m}$ & $\begin{array}{l}\text { Lower values indicate canopy is too sparse, higher values indicate shading. Values will } \\
\text { vary with variety, shoot length (Shaulis \& Smart, 1974; Shaulis, 1982; Smart, 1988; data } \\
\text { presented this paper). }\end{array}$ \\
\hline \multicolumn{3}{|l|}{ Microclimate characters: } \\
\hline Proportion canopy gaps & $20-40 \%$ & $\begin{array}{l}\text { Higher values lead to sunlight loss, lower values can be associated with shading (Smart } \\
\text { \& Smith, 1988; Smart 1988). }\end{array}$ \\
\hline Leaf layer number (LLN) & $1-1,5$ & $\begin{array}{l}\text { Higher values associated with shading, lower values with incomplete sunlight intercep- } \\
\text { tion (Smart, } 1988 \text { and literature cited for principle } 3 \text { ). }\end{array}$ \\
\hline Proportion exterior fruit & $50-100 \%$ & Interior fruit has composition defects (literature cited for principle 3). \\
\hline Proportion exterior leaves & $80-100 \%$ & Shaded leaves cause yield and fruit composition defects (literature cited for principle 3 ). \\
\hline
\end{tabular}


$5,555 \mathrm{~m}$ row/ha $\mathrm{SA}=26,944 \mathrm{~m}^{2} / \mathrm{ha}$

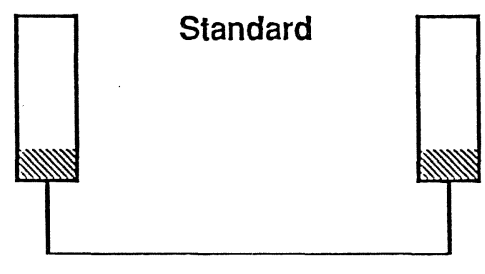

$2,778 \mathrm{~m}$ row/ha $S A=10,556 \mathrm{~m}^{2} / \mathrm{ha}$

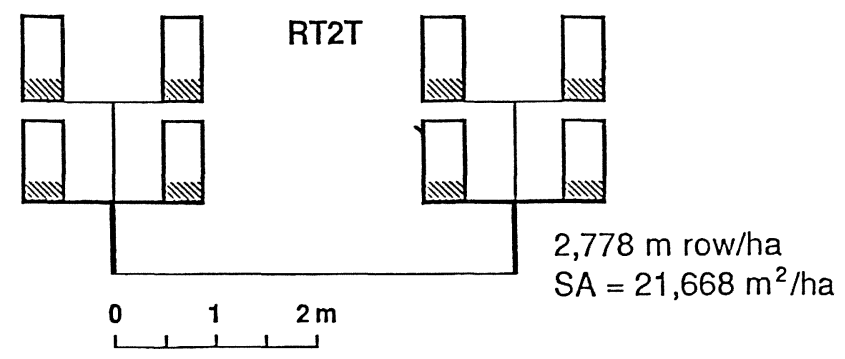

FIGURE 2

Cross-sectional dimensions of three training systems drawn to scale, along with calculations of row length/ha and canopy surface area. TK3T is Te Kauwhata Three Tier; Standard is vertically shoot positioned, non divided canopy, and RT2T is Ruakura Twin Two Tier.

(RT2T) and 'Standard' vertically shoot positioned (STD) with $3,6 \mathrm{~m}$ row spacing. The RT2T system was designed with the before listed principles 1 to 5 in mind. Within row spacing is $2,0 \mathrm{~m}$. The first harvest was 1985 , and since the 1987 vintage yields have been relatively stable as canopies have filled their allotted space.

Results will be presented here for three treatments only TK3T, RT2T and STD, (see Figure 2) with fruit composition and wine quality assessments for the 1988 vintage and yield components for the 1989 vintage. In general, yields for the 1989 vintage were higher than for 1988 , due to higher cluster numbers for the top tier of RT2T and TK3T.

Experimental wine was made from each replicate using $20-40 \mathrm{~kg}$ fruit lots fermented on skins to dryness and sterile filtered to avoid confounding effects of malolactic fermentation. Wine sensory assessment was carried out when the wines were 7 months old, using 7 experienced industry judges. The judges were evaluated for consistency and discrimination ability. The scorecard used in the sensory evaluation used six characters (colour density and hue, fruit character on nose and palate, palate structure and overall acceptability), each assessed out of 7 points. Results from this card correlated well with the three character card assessing colour (ex 3), nose (7), palate (10), and total (20) normally used in New Zealand and Australia (Gravett \& Smart, unpublished data). Standard wine analyses were made and included spectral analysis by Somers \& Evans (1977) method.

Figure 2 shows the dimensions of the three systems to be discussed, along with the calculated canopy surface area. The TK3T system has a SA greater than the optimum cited in Table 3, while the RT2T was at the optimum and the nondivided STD canopy with wide row spacing was about half the optimum value.

Effect of tier height on yield, growth and quality: The TK3T trellis provides unique insight into effects of shade on yield, growth, fruit composition and wine quality. The TK3T was included in this trial as a test for principle 2 , in that the ratio of canopy height to alley width is $1,8: 1$, in obvious violation of the 1:1 guideline. Thus lower tiers are shaded at the canopy exterior. It is possible to see the effect of varying the height to alley width ratio on vine performance by comparing different tier heights. Individual vines with $6 \mathrm{~m}$ cordon length were trained to each height and pruned to 80 nodes (13,3 nodes/m) to minimise within-canopy shading (see Table 4).

The top tier produced five times the yield and four times the pruning mass and three times cane mass, of the lowest tier (Table 5). The middle tier was intermediate. These differences are of similar order to the calculated mean light flux density at the midpoint of the fruiting zone, taken from Figure 1. Also shown in Table 5 are the height: alley width ratios calculated at the fruit zone midpoint. All the yield components bud break, fruitfulness (clusters/shoot), berry number and berry mass were reduced for lower tiers, with the last two being the most sensitive to shading.

Trends in fruit composition were similar to yield (Table 6) with top tier showing advanced maturity. Sugar accumulation was delayed for the lower tiers with the effect evident already at veraison and persisting till harvest. Maximum differences from top to bottom were $2,9^{\circ}$ Brix at veraison and $4,2^{\circ}$ Brix at harvest. There were smaller differences with acidity and $\mathrm{pH}$, with maximum differences of $1,1^{\circ} \mathrm{Brix}$ and $0,07 \mathrm{pH}$ units at harvest. Berry mass differences were substantial between tiers, a maximum of $0,68 \mathrm{~g}$ at harvest. As denoted by the proportion of red berries at veraison sampling, the top tier fruit commenced colouring earlier than both middle and lower tiers.

Fruit composition trends between tiers were further reflected in wine analyses (Table 7). Lower tiers had higher wine $\mathrm{K}$ and $\mathrm{pH}$, and lower titratable acidity and tartaric acid. The difference from top to bottom tier respectively was 300 $\mathrm{mg} / \mathrm{l} \mathrm{K}, 0,15 \mathrm{pH}$ units, $1,3 \mathrm{~g} / \mathrm{l}$ titratable acidity and $0,4 \mathrm{~g} / \mathrm{l}$ tartaric acid. Wine colour density was higher for the top tier as was also the concentration of anthocyanins, ionised anthocyanins and phenols. In turn these differences were expressed in the sensory scores, with all components except 'fruit on the nose' showing significant effect of tier position. Wines from the top tier scored 4,9 ex 7 for overall acceptability, 4,6 for the middle tier and 3,8 for the bottom tier. Lower and more shaded tiers produced wine with less colour and fruit character, and less full palate. 
TABLE 5

Effect of tier height of TK3T on yield and yield components and growth. Cabernet franc, Rukuhia, 1988-1989 season.

\begin{tabular}{|c|c|c|c|c|}
\hline Character assessed & Top & Middle & Bottom & LSD \\
\hline Cordon length/vine & 5,68 & 5,72 & 5,69 & $-\mathrm{b}$ \\
\hline Yield (kg/vine) & 21,8 & 8,2 & 4,3 & 3,8 \\
\hline Clusters/vine & 169 & 120 & 89 & 9 \\
\hline Berry mass (g) & 1,40 & 0,99 & 0,88 & 0,11 \\
\hline Nodes retained/vine & 80 & 80 & 79 & - \\
\hline Shoots/vine & 87 & 72 & 70 & 3 \\
\hline Total cane mass (kg vine) & 4,1 & 1,3 & 1,0 & 0,3 \\
\hline Percent bud break & 109 & 91 & 89 & 4 \\
\hline Clusters/shoot & 1,94 & 1,67 & 1,29 & 0,12 \\
\hline Bunch mass (g) & 129 & 68 & 48 & 19 \\
\hline Berry number & 92 & 69 & 54 & 11 \\
\hline Yield $(\mathrm{g}) /$ node retained & 273 & 102 & 55 & 47 \\
\hline Yield $(\mathrm{g}) /$ shoot & 249 & 114 & 63 & 42 \\
\hline Yield/pruning ratio & 5,4 & 6,8 & 4,6 & 1,3 \\
\hline Cane mass (g) & 47,5 & 17,3 & 14,1 & 4,6 \\
\hline Nodes retained/m cordon & 14,1 & 13,9 & 13,8 & - \\
\hline Shoots $/ \mathrm{m}$ cordon & 15,4 & 12,6 & 12,3 & 0,6 \\
\hline Clusters/m cordon & 29,8 & 21,0 & 15,7 & 1,8 \\
\hline Yield $(\mathrm{kg}) / \mathrm{m}$ cordon & 3,85 & 1,43 & 0,76 & 0,70 \\
\hline Total cane mass $(\mathrm{kg}) / \mathrm{m}$ cordon & 0,73 & 0,22 & 0,17 & 0,05 \\
\hline Berries/m cordon & 2740 & 1440 & 860 & 430 \\
\hline Calculated light (relative) ${ }^{\mathrm{a}}$ & 100 & 57 & 31 & NA \\
\hline Height: alley ratio at fruit zone midpoint & 0,40 & 0,88 & 1,43 & NA \\
\hline
\end{tabular}

${ }^{a}$ calculated from Fig. 1 for midpoint of fruit zone.

${ }^{\mathrm{b}}$ not significant indicated by -

$\mathrm{NA}=$ not applicable

Note: Data for ARG 1 and $1202 \mathrm{C}$ rootstocks combined.

TABLE 6

Effect of tier height of TK3T on fruit composition.

Cabernet franc, Rukuhia, 1987-1988 season.

\begin{tabular}{|c|c|c|c|c|}
\hline Character assessed & Top & Middle & Bottom & LSD \\
\hline $\begin{array}{l}\text { Veraison } 3 \text { March } \mathbf{1 9 8 8}^{1} \\
\text { Sugar }\left({ }^{\circ} \text { Brix }\right) \\
\text { Titratable acidity }(\mathrm{g} / \mathrm{l}) \\
\text { pH } \\
\% \text { red berries } \\
\text { Berry mass }(\mathrm{g})\end{array}$ & $\begin{array}{c}12,1 \\
24,9 \\
2,72 \\
95 \\
1,39\end{array}$ & $\begin{array}{c}9,5 \\
24,0 \\
2,65 \\
69 \\
1,07\end{array}$ & $\begin{array}{c}9,2 \\
24,0 \\
2,67 \\
38 \\
0,86\end{array}$ & $\begin{array}{c}0,8 \\
-\mathrm{a} \\
0,05 \\
20 \\
0,19\end{array}$ \\
\hline $\begin{array}{l}\text { Harvest } 20 \text { April } 1988^{1} \\
\text { Sugar }\left({ }^{\circ} \text { Brix }\right) \\
\text { Titratable acidity }(\mathrm{g} / \mathrm{l}) \\
\mathrm{pH} \\
\text { Berry mass }(\mathrm{g}) \\
\text { Yield }(\mathrm{kg} / \mathrm{vine}) \\
\% \text { rot }\end{array}$ & $\begin{array}{c}19,3 \\
10,4 \\
2,95 \\
1,67 \\
13,2 \\
5,2\end{array}$ & $\begin{array}{c}15,9 \\
9,6 \\
2,95 \\
1,22 \\
10,4 \\
0,2\end{array}$ & $\begin{array}{c}15,1 \\
9,3 \\
3,02 \\
0,99 \\
7,3 \\
0,4\end{array}$ & $\begin{array}{c}1,6 \\
0,9 \\
0,05 \\
0,17 \\
1,8 \\
1,9\end{array}$ \\
\hline $\begin{array}{l}\text { Must composition }^{2} \\
\text { Sugar }\left({ }^{\circ} \text { Brix }\right) \\
\text { Titratable acidity }(\mathrm{g} / \mathrm{l}) \\
\mathrm{pH} \\
\text { Malic acid }(\mathrm{g} / \mathrm{l})\end{array}$ & $\begin{array}{c}19,5 \\
10,0 \\
3,02 \\
4,5\end{array}$ & $\begin{array}{c}17,0 \\
9,7 \\
2,98 \\
3,9\end{array}$ & $\begin{array}{c}16,7 \\
9,5 \\
3,04 \\
3,9\end{array}$ & $\begin{array}{c}1,4 \\
- \\
- \\
0,4\end{array}$ \\
\hline
\end{tabular}

${ }^{a}$ not significantly different indicated by -

${ }^{1}$ Data for ARG1 and 1202C rootstocks combined.

${ }^{2}$ Data for $1202 \mathrm{C}$ rootstock only. 
Effect of RT2T training: The trial allowed comparisons between RT2T and STD trellis systems, but also comparisons were made within the RT2T plots. For each RT2T plot of six vines, there were two 'big' vines and four 'small' vines arranged in a $2 \times 2$ factorial combination with tier position ('up' and 'down'). Any one vine was trained to only one height. 'Big' vines had $12 \mathrm{~m}$ of cordon and 160 nodes retained, while 'small' vines had $6 \mathrm{~m}$ of cordon and 80 nodes retained, both at 13,3 nodes/m cordon. Shoot growth was devigorated on big vines because of high node number retained at winter pruning (Smart et al., 1989). Thus despite similar shoot spacing, the canopy of big vines was less dense than for small vines (Smart \& Smith, 1988). Data for these comparisons are shown in Tables 8, 9 and 10, and where height by vine size interactions are significant these data are shown in Table 11.

Table 8 presents the effect of vine size and tier height on yield and growth and also compares RT2T plots including both big and small vines with STD. RT2T more than doubles yield of STD due to greater cordon (canopy) length, more nodes retained (by 28), higher bud break (by 24\%), clusters per shoot (by 0,1$)$, and berry number per bunch (by 21). Large differences in yield per retained node (by $90 \mathrm{~g}$ ) and per shoot (by $50 \mathrm{~g}$ ) between RT2T and STD result. These yield responses are in accord with responses noted previously (Smart \& Smith, 1988), and correspond to the STD vines having a dense shaded canopy with the RT2T canopy being open. STD vines are 'unbalanced' with excessive vegetative growth as indicated by low yield/ pruning ratios and high cane mass.

The yield, yield component and growth differences between the two tier heights for the RT2T are similar to those recorded for the top two tiers of TK3T and require no further discussion. There was less effect on yield components of 'big' versus 'small' vines. Percent bud break of small vines was slightly higher (by 17\%), as is expected with fewer retained nodes per vine (Smart \& Smith, 1988). 'Big' vines showed better balance between vegetative growth and fruit than 'small' vines, as indicated by higher yield per shoot (by $21 \mathrm{~g}$ ), lower yield to pruning ratio (by 2,7), and lower cane mass (by $7 \mathrm{~g}$ ). There was little interaction between level and size. Lower tier big vines had more clusters per shoot, and lower total cane mass per $m$ of cordon (Table 11).

Fruit composition was similar for RT2T and STD vines at veraison (Table 9). Fruit from small vines had higher acidity than big vines at veraison by $1,3 \mathrm{~g} / \mathrm{l}$. Interactions between size and tier position in the RT2T are explained by lower tier small vines having higher $\mathrm{pH}$, and berry size differences were less for the bottom tier than the top (Table 11). At harvest there were significant differences in fruit composition. STD vines had more sugar (by $0,9^{\circ} \mathrm{Brix}$ ), higher $\mathrm{pH}($ by 0,13 ) and higher bunch rot (by 18\%). Top tier vines had higher sugar

TABLE 7

Effect of tier height of TK3T on wine analysis and sensory scores. Cabernet franc, Rukuhia 1987-1988 season.

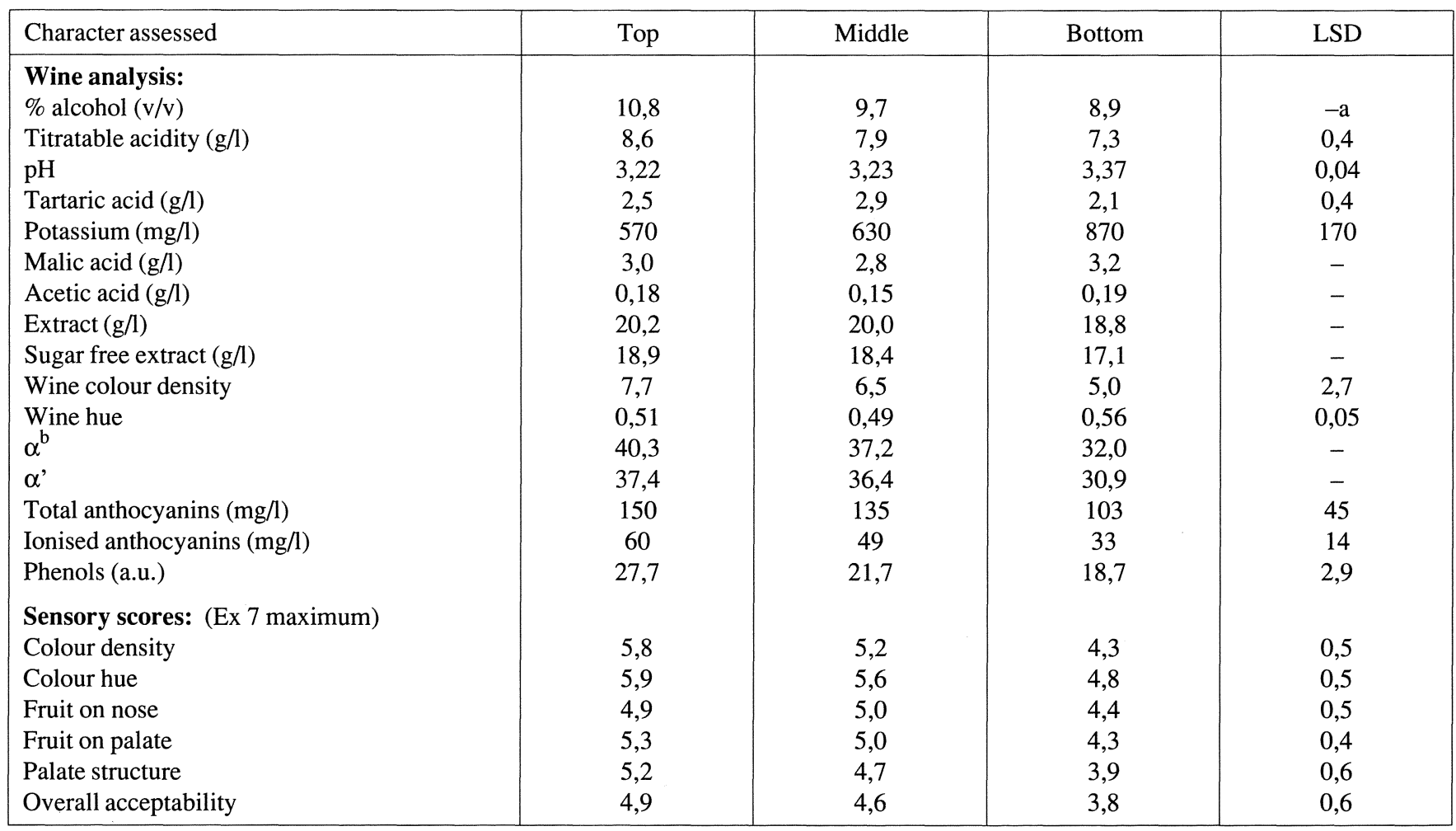

${ }^{a}$ not significantly different indicated by -

${ }^{\mathrm{b}} \alpha$ proportion ionised anthocyanins

$\alpha$ proportion ionised anthocyanins without $\mathrm{SO}_{2}$

Note: Data for $1202 \mathrm{C}$ rootstock only. 
TABLE 8

Effect of tier height and vine size of RT2T compared with standard trellis on yield, yield components and growth. Cabernet franc, Rukuhia, 1988-1989 season.

\begin{tabular}{|c|c|c|c|c|c|c|c|c|c|c|}
\hline \multirow{2}{*}{$\begin{array}{l}\text { Character } \\
\text { assessed }\end{array}$} & \multicolumn{3}{|c|}{ Trellis } & \multicolumn{3}{|c|}{ Tier height } & \multicolumn{3}{|c|}{ Vine size } & \multirow{2}{*}{$\begin{array}{c}\text { Interaction } \\
(\text { height }+ \text { size })\end{array}$} \\
\hline & STD & RT2T & LSD & UPPER & LOWER & LSD & BIG & SMALL & LSD & \\
\hline Cordon length/vine (m) & 1,91 & 7,82 & 0,84 & 7,63 & 8,0 & - & 12,10 & 5,68 & 0,69 & $-\mathrm{a}$ \\
\hline Yield (kg/vine) & 8,9 & 21,5 & 1,8 & 29,6 & 13,4 & 2,0 & 31,5 & 16,5 & 2,1 & 0,001 \\
\hline Clusters/vine & 116 & 214 & 12 & 254 & 173 & 22 & 306 & 167 & 23 & - \\
\hline Berry mass (g) & 1,24 & 1,24 & - & 1,37 & 1,04 & 0,07 & 1,23 & 1,17 & 0,07 & - \\
\hline Nodes retained/vine & 79 & 107 & NA & 107 & 107 & NA & 160 & 80 & NA & NA \\
\hline Shoots/vine & 65 & 111 & 5 & 120 & 102 & 85 & 153 & 90 & 5 & 0,001 \\
\hline Total cane mass (kg/vine) & 3,7 & 3,1 & 0,3 & 3,9 & 2,2 & 0,2 & 3,7 & 2,8 & 0,3 & - \\
\hline Percent bud break & 83 & 107 & 4 & 115 & 99 & 5 & 96 & 113 & 5 & - \\
\hline Clusters/shoot & 1,79 & 1,89 & 0,07 & 2,11 & 1,67 & 0,16 & 2,00 & 1,84 & - &, 04 \\
\hline Bunch mass (g) & 77 & 97 & 7 & 117 & 78 & 9 & 100 & 96 & - & - \\
\hline Berry number & 60 & 81 & 13 & 87 & 75 & 10 & 80 & 81 & - & - \\
\hline Yield $(\mathrm{g}) /$ node retained & 113 & 203 & 18 & 280 & 126 & 18 & 197 & 206 & - & - \\
\hline Yield $(\mathrm{g}) /$ shoot & 137 & 187 & 15 & 244 & 130 & 13 & 201 & 180 & 15 & - \\
\hline Yield/cane mass ratio & 2,5 & 6,8 & 0,3 & 7,6 & 6,0 & 0,8 & 8,6 & 5,9 & 0,9 & - \\
\hline Cane mass (g) & 58 & 28 & 3 & 34 & 22 & 3 & 24 & 31 & 3 & - \\
\hline Nodes retained/m cordon & 41,4 & 13,9 & 1,2 & 14,1 & 13,4 & - & 13,4 & 14,2 & - & - \\
\hline Shoots/m cordon & 34,1 & 14,9 & 1,1 & 16,2 & 13,5 & 0,8 & 12,8 & 15,9 & 0,9 & - \\
\hline Clusters/m cordon & 60,7 & 28,3 & 3,1 & 34,3 & 22,2 & 2,7 & 25,7 & 29,6 & 2,8 & - \\
\hline Yield $(\mathrm{kg}) / \mathrm{m}$ cordon & 4,67 & 2,84 & 0,52 & 3,95 & 1,72 & 0,25 & 2,66 & 2,92 & - & - \\
\hline Total cane mass $(\mathrm{kg}) / \mathrm{m}$ cordon & 1,97 & 0,43 & 0,13 & 0,56 & 0,31 & 0,03 & 0,31 & 0,49 & 0,03 & 0,004 \\
\hline Berries $/ \mathrm{m}$ cordon & 3666 & 2259 & 406 & 2879 & 1638 & 307 & 2102 & 2415 & - & - \\
\hline
\end{tabular}

${ }^{\mathrm{a}}$ not significantly different indicated by -

NA $=$ not applicable

Note: Data for ARG1 and 1202C rootstocks combined.

TABLE 9

Effect of tier height and vine size on fruit composition of RT2T compared with standard. Cabernet franc, Rukuhia, 1987-1988 season.

\begin{tabular}{|l|c|c|c|c|c|c|c|c|c|c|}
\hline \multirow{2}{*}{$\begin{array}{c}\text { Character } \\
\text { assessed }\end{array}$} & \multicolumn{3}{c|}{ Trellis } & \multicolumn{3}{c|}{ Tier height } & \multicolumn{3}{c|}{ Vine size } & Interaction \\
\cline { 2 - 9 } (height + size)
\end{tabular}

${ }^{a}$ not significantly different indicated by -

${ }^{1}$ Data for ARG1 and $1202 \mathrm{C}$ rootstocks combined.

2 Data for STD vs RT2T for ARG1 rootstock only, remainder for 1202C 
TABLE 10

Effect of tier height and vine size of RT2T compared with standard on wine analysis and sensory scores. Cabernet franc, Rukuhia, 1987-1988 season.

\begin{tabular}{|c|c|c|c|c|c|c|c|c|c|c|}
\hline \multirow{2}{*}{$\begin{array}{l}\text { Character } \\
\text { assessed }\end{array}$} & \multicolumn{3}{|c|}{ Trellis } & \multicolumn{3}{|c|}{ Tier height } & \multicolumn{3}{|c|}{ Vine size } & \multirow{2}{*}{$\begin{array}{c}\text { Interaction } \\
\text { (height }+ \text { size })\end{array}$} \\
\hline & STD & RT2T & LSD & UPPER & LOWER & LSD & BIG & SMAAL & LSD & \\
\hline $\begin{array}{l}\text { Wine analysis: } \\
\% \text { alcohol }(\mathrm{V} / \mathrm{V})\end{array}$ & 10,7 & 10,2 & - & 10,8 & 8,9 & 0,9 & 9,5 & 10,2 & - & $-^{\mathrm{a}}$ \\
\hline Titratable acidity $(\mathrm{g} / \mathrm{l})$ & 7,7 & 8,4 & - & 8,5 & 8,1 & 0,3 & 8,4 & 8,2 & - & 0,03 \\
\hline $\mathrm{pH}$ & 3,40 & 3,19 & 0,13 & 3,18 & 3,20 & - & 3,13 & 3,25 & 0,05 & - \\
\hline Tartaric acid $(\mathrm{g} / \mathrm{l})$ & 1,7 & 2,9 & 0,7 & 2,7 & 2,8 & - & 3,0 & 2,4 & 0,3 & - \\
\hline $\mathrm{K}(\mathrm{mg}$ & 920 & 720 & 130 & 680 & 660 & - & 570 & 770 & 100 & - \\
\hline Malic acid (g/l) & 3,3 & 2,7 & 0,3 & 3,1 & 3,0 & - & 2,9 & 3,2 & - & - \\
\hline Acetic acid $(\mathrm{g} / \mathrm{l})$ & 0,23 & 0,18 & - & 0,17 & 0,17 & - & 0,18 & 0,17 & - & - \\
\hline Extract $(\mathrm{g} / \mathrm{l})$ & 23,8 & 20,3 & - & 20,8 & 18,8 & 1,6 & 18,7 & 20,9 & 1,6 & - \\
\hline Sugar free extract $(\mathrm{g} / \mathrm{l})$ & 22,1 & 19,0 & - & 19,3 & 17,4 & 1,5 & 17,3 & 19,4 & 1,5 & - \\
\hline Wine colour density & 3,9 & 7,0 & 2,7 & 7,0 & 5,5 & 1,0 & 6,1 & 6,5 & - & - \\
\hline Wine hue & 0,77 & 0,49 & - & 0,53 & 0,52 & - & 0,49 & 0,56 & 0,02 & 0,003 \\
\hline$\alpha^{\mathrm{b}}$ & 17 & 37 & 11 & 38 & 40 & - & 42 & 36 & - & - \\
\hline$\alpha$ & 25 & 37 & 5 & 38 & 39 & - & 40 & 36 & - & 0,04 \\
\hline Total anthocyanins $(\mathrm{mg} / \mathrm{l})$ & 161 & 165 & - & 158 & 105 & 12 & 125 & 138 & 12 & 0,05 \\
\hline Ionised anthocyanins $(\mathrm{mg} / \mathrm{l})$ & 28 & 60 & 29 & 59 & 41 & 5 & 50 & 50 & - & - \\
\hline Phenols (a.u.) & 22 & 24 & - & 25 & 17 & 2 & 21 & 22 & - & - \\
\hline Sensory scores: & & & & & & & & & & \\
\hline Colour density & 3,8 & 4,6 & 0,6 & 5,5 & 5,2 & - & 5,1 & 5,6 & - & - \\
\hline Colour hue & 3,6 & 5,9 & 0,7 & 5,8 & 5,5 & 0,2 & 5,7 & 5,6 & - & 0,01 \\
\hline Fruit on nose & 3,7 & 5,1 & 0,5 & 5,2 & 5,2 & - & 5,0 & 5,4 & 0,1 & 0,01 \\
\hline Fruit on palate & 3,9 & 5,5 & 0,6 & 5,4 & 5,1 & 0,2 & 5,0 & 5,6 & 0,2 & 0,04 \\
\hline Palate structure & 3,8 & 5,2 & 0,4 & 5,2 & 4,8 & 0,2 & 4,7 & 5,2 & 0,2 & - \\
\hline Overall acceptability & 3,5 & 5,1 & 0,6 & 5,0 & 4,6 & 0,3 & 4,5 & 5,0 & 0,3 & - \\
\hline
\end{tabular}

${ }^{\mathrm{a}} \alpha$ proportion ionised anthocyanins.

$\alpha$ proportion ionised anthocyanins after removing $\mathrm{SO}_{2}$ effect.

${ }^{\mathrm{b}}$ not significantly different indicated by -

Note: Data for standard vs RT2T for ARG1 rootstock, remainder for $1202 \mathrm{C}$ rootstock.

TABLE 11

Details of significant tier hight X vine size interactions, RT2T. Cabernet franc, Rukuhia, 1987-1988 and 1988-1989 seasons.

\begin{tabular}{|c|c|c|c|c|c|}
\hline Character assessed & Upper - big & Upper - small & Lower big & Lower - small & LSD \\
\hline \multicolumn{6}{|l|}{ From Table 8: } \\
\hline Yield (kg/vine) 1989 & 43,0 & 22,9 & 20,0 & 10,1 & 3,0 \\
\hline Shoots/vine & 168 & 96 & 137 & 84 & 7,2 \\
\hline Clusters/shoot & 2,10 & 2,12 & 1,89 & 1,56 & 0,24 \\
\hline Total cane mass $(\mathrm{kg} / \mathrm{m}$ cordon $)$ & 0,40 & 0,64 & 0,22 & 0,35 & 0,05 \\
\hline \multicolumn{6}{|l|}{ From Table 9: } \\
\hline $\mathrm{pH}$, veraison & 2,23 & 2,16 & 2,65 & 2,68 & 0,07 \\
\hline Berry mass $(\mathrm{g})$, veraison & 1,51 & 1,26 & 1,03 & 1,12 & 0,20 \\
\hline Yield/vine (kg) 1988 & 28,7 & 14,3 & 22,6 & 13,0 & 2,6 \\
\hline Must titratable acidity $(\mathrm{g} / \mathrm{l})$ & 9,3 & 9,7 & 9,7 & 9,0 & 0,6 \\
\hline Must malic acid $(\mathrm{g} / \mathrm{l})$ & 4,3 & 4,9 & 4,2 & 4,0 & 0,6 \\
\hline \multicolumn{6}{|l|}{ From Table 10: } \\
\hline Wine tritratable acidity $(\mathrm{g} / \mathrm{l})$ & 8,4 & 8,6 & 8,4 & 7,8 & 0,5 \\
\hline Wine hue & 0,49 & 0,58 & 0,50 & 0,53 & 0,02 \\
\hline$a^{\prime}$ & 37,4 & 38,2 & 43,0 & 34,8 & 5,8 \\
\hline Total anthocyanins $(\mathrm{mg} / \mathrm{l})$ & 157 & 158 & 92 & 118 & 18 \\
\hline Sensory score - hue & 5,9 & 5,5 & 5,4 & 5,6 & 0,4 \\
\hline Sensory score - fruit on nose & 5,2 & 5,3 & 4,6 & 5,4 & 0,5 \\
\hline Sensory score - fruit on palate & 5,3 & 5,7 & 4,6 & 5,4 & 0,4 \\
\hline
\end{tabular}


(by $1,2^{\circ}$ Brix) and berry weight (by $0,34 \mathrm{~g}$ ), and there was no effect of vine size. Interactions are due to lower tier large vines having higher titratable acidity, while there was little effect of vine size for the bottom tier in malic acid compared to the top tier (Table 11).

The fruit composition effects carried through to the wine, with STD wines having higher $\mathrm{pH}$ (by 0,21 ), $\mathrm{K}$ (by $200 \mathrm{~m} / \mathrm{l}$ ) and malic acid (by 0,6 g/l) and lower tartaric acid (by $1,2 \mathrm{~g} / \mathrm{l}$ ), see Table 10. Wines made from fruit from the top tier had more acidity and extract, while wines from big vine fruit had lower $\mathrm{pH}, \mathrm{K}$ and extract and higher tartaric acid than for wine from small vines. Interactions were caused by low values of titratable acidity for lower tier small vines (Table 11). Wine spectral analysis showed RT2T wines had more colour density (by 3,1 units), and ionised anthocyanins (by $32 \mathrm{mg} /$ ) than wines from the STD. Similar patterns were evident when wines from the top and bottom tiers were compared. Big vines produced wine with lower hue values and lower anthocyanins. There was little effect from vine size in the bottom tier on colour hue, however small vines in the bottom tier had lower $\alpha$ ' and higher total anthocyanins (Table 11).

Judges recorded a clear preference for RT2T wines over STD in all characters assessed. These wines had better colour, more fruit character and were fuller on the palate. Overall acceptability rating was 5,1 ex 7 for RT2T and 3,5 for STD. Wines from the top tier were preferred to those from the bottom tier, and from small vines to big vines. These differences were however small. Interactions were due to lower values for bottom tier big vines in colour hue, and fruit on nose and palate (Table 11)

Yield and quality relationship: The relationship between yield and quality for RT2T and TK2T vines is presented in Figures $3 a$ and $b$. Figure $3 a$ shows the relationship between yield and sensory score for overall acceptability for different tier heights for TK3T and up-down and bigsmall comparisons for RT2T all using $1202 \mathrm{C}$ rootstock. Fig-

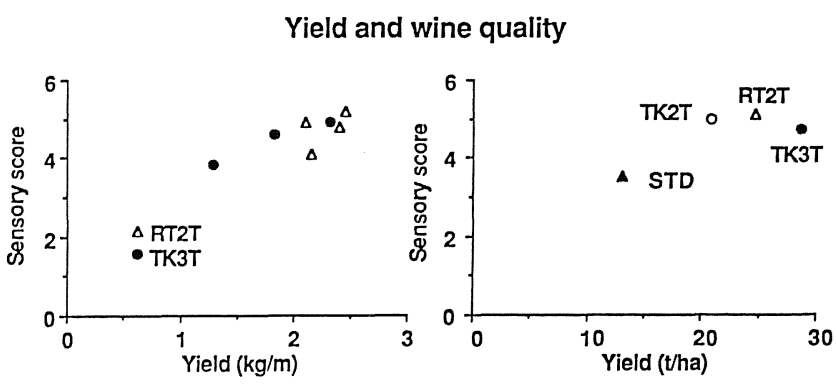

FIGURE 3

Relationship between yield and sensory evaluation score ex 7 for overall acceptability. Figure on left is data for three tiers of TK3T, and four combinations of vine size and tier height for RT2T. Yield results expressed per m canopy length. Figure on right is for STD, TK2T, RT2T, TK3T with composite fruit samples taken over two heights for TK2T, three heights for TK3T, and four combinations of vine size and tier height for RT2T. Cabernet franc, Rukuhia, 1988 vintage. ure $3 b$ shows the relationship for wines made from all vines in the plot (i.e. composite over tier height and vine size, all ARG1 rootstock). Note that as shading is decreased, yield and sensory score are simultaneously improved.

Shading caused by fruit: For vertically shoot positioned canopies where the fruit is within a constricted region there is a possibility that clusters may contribute to shading of the renewal zone. For the productive RT2T trellis for example, while the canopy is of low density ( 15 shoots $/ \mathrm{m})$ the shoots are very fruitful $(190 \mathrm{~g} / \mathrm{shoot})$ and the basal shoot zone is literally a wall of fruit. Measurements were made in April 1989 on the Cabernet franc trial to determine cluster projected area in relation to canopy surface area. Cluster shape was approximated as a truncated triangle, and characteristic dimensions measured on a sample of 20 clusters. The average cluster projected area was $102 \mathrm{~cm}^{2}$, and so for average cluster mass of $114 \mathrm{~g}$, this corresponds to $0,89 \mathrm{~cm}^{2}$ projected area/g fruit mass. The fruit zone height was on average $26 \mathrm{~cm}$ high, or $2620 \mathrm{~cm}^{2} /$ canopy surface area per $\mathrm{m}$ cordon. The area sampled had 31 clusters per m cordon, or $3190 \mathrm{~cm}^{2}$ projected cluster area per $\mathrm{m}$ cordon. Therefore, the average cluster layer number (CLN, ratio cluster area: canopy fruit zone area) was 1,21 . Since clusters are opaque, the clusters themselves can contribute significantly to shade in the cluster region. For the value of $1,5 \mathrm{~kg}$ fruit $/ \mathrm{m}^{2}$ canopy surface area of Table 4 , the cluster surface area would be about $1340 \mathrm{~cm}^{2} / \mathrm{m}^{2}$ canopy surface area, or $13 \%$.

\section{CONCLUSIONS}

This paper has condensed results of recent studies into guidelines for canopy management. These are presented as five 'principles'. Optimal values of 21 performance indices and character shave been incorporated into a winegrape canopy ideotype. Along with the field techniques of point quadrat and canopy scoring which are described, these measurements will assist in diagnosing problem canopies.

Recent research results are also presented which serve to confirm some of the principles that introduced this paper. Results presented from the Te Kauwhata Three Tier trellis system reinforce principle 2 , which deals with the spacing of vertical foliage walls. The recommendation is that the height to alley width ratio should not exceed about $1: 1$. Provided this value is not exceeded, light levels at the canopy exterior should not drop below about $15 \%$ of ambient on a horizontal plane (Figure 1). Results presented for the TK3T comparison show that as the height: alley width ratio increases, so does yield and wine quality decrease. All yield components are affected by shade, with berry number and berry mass most sensitive. Fruit maturation was delayed by shade, and judges scored a clear preference for wines produced from top tier fruit which had least shading. These data gave further clear evidence for the negative effects of shade on yield and wine quality.

The Ruakura Twin Two Tier system was designed with the principles and canopy ideotype listed above in mind. Results presented here confirmed the importance of these principles. Yield is doubled, fruit composition is improved and wine quality increased. The bottom tier however, has less yield and lower quality than the top tier. We are now evaluat- 
ing a modified form of the RT2T with the bottom tier of shoots growing downwards. In this configuration, the two fruiting/renewal zones will be closer together, and at mid canopy height, which will reduce yield, fruit composition and wine quality differences between the two tiers (Smart et al., unpublished data).

The RT2T trial also permitted an evaluation of the effect of vine size. That is, vines with large retained node numbers (160) were compared with those pruned to 80 nodes, but where canopy length was proportional to retained node number. Use of large vines caused desirable shoot devigoration, assisting in achieving a desirable canopy microclimate for these vigorous vines. The results suggest that a preferred planting arrangement would be to have large vines on the top tier and small vines on the bottom tier, which will help reduce fruit composition and wine quality differences between tiers. The large vine will tend to counter the tendency of the top tier to promote vigour and fruit ripening as will the small vines counter the tendency of bottom tier to reduce vigour and delay ripening. The results are encouraging further research into the use of low vine density and complex trellis systems on high fertility sites.

Adoption of the canopy management techniques outlined here will have a major impact on winegrape production, fruit composition and wine quality from vigorous vineyards. This viewpoint is supported by literature citation and recent experimental data presented here. While these results are contradictory to the common opinion that high yield causes reduced wine quality, they demonstrate that improving canopy microclimate for dense canopies can simultaneously improve yield and quality.

\section{LITERATURE CITED}

BRAVDO, B., HEPNER, Y., LOINGER, C., COHEN, S. \& TABACKMAN, H., 1985. Effect of crop level and crop load on growth, yield, must and wine composition and quality of Cabernet Sauvignon. Am. J. Enol. Vitic. 36, 125-131.

CARBONNEAU, A., 1985. Trellising and canopy management for cool climate viticulture. Proc. First Int. Symp. Cool Climate Viticulture and Enology, June, 1984 Eugene, Ore. Oregon State University, 158-174.

CARBONNEAU, A., CASTERAN, P. \& LE CLAIR, P., 1978. Essai de determination en biologie de la plante entiere, de relations essentielles entre le bioclimat natural, la physiologie de la vigne et la composition du raisin. Ann. Amelior, Plant 28, 195-221.

CARBONNEAU, A. \& CASTERAN, P., 1987. Interactions training system x soil $x$ rootstock with regard to vine ecophysiology, vigour, yield and red wine quality in the Bordeaux area. Actta Horticulturae 206, 119-140.

CASTERAN, P. \& CARBONNEAU, A., 1987. Etude de la fertilite des bourgeons, de la production et de la maturation en fonction du systems de conduite de la vigne. Proc. 3rd Int. Symp. Physiologie de la Vigne, June 1986, Bordeaux. OIV., 405-412.

CHAMPAGNOL, F., 1984. Elements de physiologie de la vigne et du viticulture generale. F. Champagnol.

CRIPPEN, D. \& MORRISON, J., 1986a. The effects of sun exposure on the compositional development of Cabernet Sauvignon berries. Am. J. Enol. Vitic. 37, 235-242

CRIPPEN, D., \& MORRISON, J., 1986b. The effects of sun exposure on the phenolic content of Cabernet Sauvignon berries during development. Am. J. Enol. Vitic. 37 243-247.

CLINGELEFFER, P., 1989. Update: minimal pruning of cordon trained vines (MPCT) Aust. Grapegrower and Winemaker 304, 78-83.

CULLEN, V., 1988. Canopy management for Sauvignon Blanc vines at Margaret River Proc. Second Int. Symp. Cool Climate Viticulture and Oenology, January, 1988 Auckland, New Zealand. NZ Society for Vitic. and Oenol., 139-143.

DONALD, C., 1968. The design of a wheat ideotype. Proc. Third Int. Wheat Genetics Symp. Canberra. Aust. Acad. Sciences.

ENGLISH, J.; BLEDSOE, A. \& MAROIS, J., 1989. Influence of leaf removal from the cluster zone on the components of evaporative potential within grapevine canopies. Am. J. Enol. Vitic. 40, (In press).

FREESE, P., 1988. Canopy modification and fruit composition. Proc. Second Int. Symp.
Cool Climate Viticulture and Oenology, January, 1988, Auckland, New Zealand. NZ Soc. for Vitic. and Oenol., 134-136.

GUBLER, W., MAROIS, J., BLEDSOE, A. \& BETTIGA, L., 1987. Control of Botrytis bunch rot of grapes with canopy management. Plant Disease 71, 599-601.

HUNTER, J. \& VISSER, J., 1988. Distribution of 14C-photosynthetate in the shoot of Vitis Vinifera L. cv. Cabernet Sauvignon. II. The effect of partial defoliation. S. Afr. J. Enol. Vitic 9, 10-15.

ILAND, P., 1988. Leaf removal effects on fruit composition. Proc. Second Int. Symp. Cool climate Viticulture and Oenology, January, 1988, Auckland, New Zealand. NZ Soc. for Vitic, and Oenol., 137-138.

INTRIERI, C., 1987. Experiences on the effect of vine spacing and trellis training system on canopy microclimate, vine performance ảnd grape quality:Acta Horticulturae 206, $69 \div 88$.

JACKSON, J. \& PALMER, J., 1972. Interception of light by model hedgerow orchards in relation to latitude, time of year and hedgerow configuration and orientation. $J$. Appl.Ecol. 9, 341-357.

JACKSON, D. \& COOMBE, B., 1988. Early bunch stem necrosis - a cause of poor set. Proc. Second Int. Symp. Cool Climate Viticulture and Oenology, January, 1988, Auckland, New Zealand. NZ Soc. for Vitic. and Oenol., 72-75.

KLIEWER, M. \& LIDER, L., 1968. Influence of cluster exposure to the sun on composition of Thompson seedless fruit. Am. J. Enol. Vitic. 19, 175-184.

KLIEWER, M. \& BLEDSOE, A., 1987. Influence of hedging and leaf removal on canopy microclimate, grape composition, and wine quality under California conditions. Acta Horticulturae 206, 157-168.

KLIEWER, M., MAROIS, J., BLEDSOE, A., SMITH, S., BENZ, M. \& SILVESTRONI, O., 1988. Relative effectiveness of leaf removal, shoot positioning, and trellising for improving winegrape composition. Proc. Second Int. Symp. Cool Climate Viticulture and Oenology, January, 1988, Auckland, New Zealand. NZ Soc. for Vitic, and Oenol, 123-126.

KLIEWER, M. \& SMART, R., 1988. Canopy manipulation for optimising vine microclimate, crop yield and composition of grapes. In: Wright, C. (Ed.). Manipulation of Fruiting. Proc. 47th Easter School in Agric. Sci. Symp. April 1988, Univ. Nottingham. Butterworths, London, 275-291.

KOBLET, W., 1987a. Effectiveness of shoot topping and leaf removal as a means of improving quality. Acta Horticulturae-206, 141-156.

KOBLET, W., 1987b. Vieux bois et performance de la vigne. Proc. 3rd Int. Symp. Physiologie de la Vigne, June 1986, Bordeaux. OIV., 418-422.

KOBLET, W., 1988. Canopy management in Swiss vineyards. Proc. Second Int. Symp. Cool Climate Viticulture and Oenology, January 1988, Auckland, New Zealand. NZ Soc. for Vitic. and Oenol., 161-164.

LAVEE, S. \& HASKAL, A., 1982. An integrated high density intensification system for tablegrapes. Proc. Grape and Wine Centennial Symp., June 1980, Davis, Calif. Univ. of Calif., 390-398.

MORRISON, J., 1988. The effects of shading on the composition of Cabernet Sauvignon grape berries. Proc. Second Int. Symp. Cool Climate Viticulture and Oenology, January 1988, Auckland, New Zealand. NZ Soc. Vitic. and Oenol., 144-146.

MURISIER, F. \& SPRING, J., 1987. Influence de la hauteur du tronc et de la densite de plantation sur le compartement de la vigne. Proc. 3rd Int. Symp. Physiologie de la Vigne, June 1986, Bordeaux, OIV 412-417.

PALMER J. \& JACKSON, J., 1977. Seasonal light interception and canopy development in hedgerow and bed system apple orchards. J. Appl. Ecol. 14, 539-549.

PEARSON, R. \& GOHEEN, A., 1988. Compendium of grape diseases. American Phytopathological Society. Minn. 93 pp.

PETERSON, J. \& SMART, R., 1975. Foliage removal effects on Shiraz grapevines. Am. J. Enol. Vitic. 26, 119-124

PSZCZOLKOWSKI, P., MARALES, A. \& CARA, S., 1985. Chemical composition of musts and wines from clusters exposed to different levels of sunlight. Ciencia and Investigation Agraria 12, 181-188.

REYNOLDS, A., 1989. Riesling grapes respond to cluster thinning and shoot density manipulation. J. Amer. Soc. Hort. Sci. 114, 364-368.

REYNOLDS, A. \& WARDLE, D., 1988. Canopy microclimate of Gewürztraminer and monoterpene levels. Proc. Second Intnl Symp. Cool Climate Viticulture and Oenology, January 1988; Auckland, New Zealand. NZ Soc. for Vitic. and Oenol., 116-122.

REYNOLDS, A., \& WARDLE, D., 1989a. Impact of various canopy manipulation techniques on growth, yield, fruit composition, and wine quality of Gewürztraminer. Am. J. Enol. Vitic. 40, 121-129.

REYNOLDS, A. \& WARDLE, D., 1989b. Effects of timing and severity of summer hedging on growth, yield, fruit composition, and canopy characteristics of de Chaunac. I. Canopy characteristics and growth parameters. Am. J. Enol. Vitic. 40, 109-129.

REYNOLDS, A., \& WARDLE, D., 1989c. Influence of fruit microclimate on monoterpene levels of Gewürztraminer. Am. J. Enol. Vitic. 40, 149-154.

SAVAGE, S. \& SALL, M., 1984. Botrytis bunch rot of grapes, the influence of selected cultural practices on infection under Californian conditions. Plant Disease 67, 771-774.

SOLARI, C., SILVESTRONI, O., GUIDICI, P. \& INTRIERI, C., 1988. Influence of topping on juice composition of Sangiovese grapevines (V. Vinifera L.). Proc. 
Second Int. Symp. Cool Climate Viticulture and Oenology, January 1988, Auckland, New Zealand. NZ Soc. for Vitic. and Oenol., 147-151.

SHAULIS, N. 1982. Responses of grapevines and grapes to spacing of and within canopies. Proc. Grape and Wine Centennial Symp., June 1980, Davis, Calif. Univ. of Calif., 353-361.

SHAULIS, N., AMBERG, H. \& CROWE, D., 1966. Response of Concord grapes to light, exposure and Geneva Double Curtain training. Proc. Am. Soc. Hortic. Sci. 89, 268-280.

SHAULIS, N. \& SMART, R., 1974. Grapevine canopies: management, microclimate and yield responses. Proc. XIXth Int. Hort. Congress, September 1974, Warsaw. 254-265.

SMART, R., 1973. Sunlight interception by vineyards. Am. J. Enol. Vitic. 24, 141-147.

SMART, R., 1974. Photosynthesis by grapevine canopies. J. Appl. Ecol. 11, 997-1000.

SMART, R., 1982. Vine manipulation to improve winegrape quality. Proc. Grape and Wine Centennial Symp., June 1980, Davis, Calif. Univ. of Calif. 362-375.

SMART, R., 1985a. Principles of grapevine canopy microclimate manipulation with implications for yield and quality: a review. Am. J. Enol. Vitic. 35, 230-239.

SMART, R., 1985b. Some aspects of climate, canopy microclimate, vine phhysiology and wine quality. Proc. First Symp. Cool Climate Viticulture and Enology, June 1984, Eugene, Oregon. Oregon State University, 1-19.

SMART, R., 1987a. The influence of light on composition and quality of grapes. Acta Horticulturae 206, 37-47.

SMART, R., 1987b. The light quality environment of vineyards. Proc. 3rd Int. Symp. Physiologie de la Vigne, June 1986, Bordeaux. OIV. 378-385.

SMART, R., 1987c. Canopy management to improve yield, fruit composition and vineyard mechanisation. Proc. Sixth Australian Wine Industry Technical Conf. July, 1986, Adelaide, SA. Australian Wine Reseaṛch Institute, 205-211.

SMART, R., 1988. Shoot spacing and canopy light microclimate. Am. J. Enol.Vitic. 39, 325-333.

SMART, R. \& SINCLAIR, T., 1976. Solar heating of grape berries. Agric. Meteorol 17, 241-259.

SMART, R. \& DRY, P., 1980. A climate classification for Australia viticultural regions. Aust. Grapegrower and-Winemaker 196, 8-16.

SMART, R., SHAULIS, N. \& LEMON, E., 1982a. The effect of Concord vineyard microclimate on yield. I. The effects of pruning, training, and shoot positioning on radiation microclimate. Am. J. Enol. Vitic. 33, 99-109.

SMART. R., SHAULIS, N. \& LEMON, E., 1982b. The effect of Concord vineyard microclimate on yield. II. The interactions between microclimate and yield expression. Am. J. Enol. Vitic. 33, 109-116.

SMART, R. \& COOMBE, B., 1983. Water relations of grapevines. In: Kozlowski, T., (Ed.). Water deficits and plant growth. Vol. VII. Academic Press, NY, 137-196.

SMART, R., ROBINSON, J. DUE, G. \& BRIEN, C., 1985a. Canopy microclimate modification for the cultivar Shiraz. I. Definition of canopy microclimate. Vitis 24, 17-31.

SMART, R., ROBINSON, J., DUE, G. \& BRIEN, C., 1985b. Canopy microclimate modification for the cultivar Shiraz. II. Effects on must and wine composition. Vitis, 24, 119-128.

SMART, R. \& SMITH, S., 1988. Canopy management: identifying the problems and practical solutions. Proc. Second Int. Symp. Cool Climate Viticulture and Oenology, January 1988, Auckland, New Zealand. NZ Soc. for Vitic. and Oenol. 109-115.

SMART, R., SMITH, S. \& WINCHESTER, R., 1988. Light quality and quantity effects on fruit ripening of Cabernet Sauvignon. Am. J. Enol. Vitic. 39, 250-258.

SMART, R. \& SHARP, K., 1989. Handbook for canopy management workshop. Viticultural Bulletin 54. MAF Ruakura Agricultural Centre, Hamilton, New Zealand, 45pp.

SMART, R., DICK, J., \& GRAVETT, I., 1989. Proc. Seventh Australian Wine Industry Technical Conf., August 1988, Adelaide, SA. Australian Wine Research Institute (In press).

SMITH, S., CODRINGTON, I., ROBERTSON, M., \& SMART, R., 1988. Viticultural and oenological implications of leaf removal for New Zealand vineyards. Proc. Second Int. Symp. Cool Climate Viticulture and Oenology, January 1988, Auckland, New Zealand. NZ Soc. Vitic. and Oenol. 127-133.

SOMERS, T. \& EVANS, M. 1977. Spectral evaluation of young red wines, anthocyan equilibria, total phenolics, free and molecular $\mathrm{SO}_{2}$, chemical age. J. Sci. Food Agric. 28, 279-287.

TRAVIS, J., 1987. Effect of canopy density on pesticide deposition and distribution in apple trees. Plant Disease 71, 613-615.

VAN DEN ENDE, B., 1984. The Tatura trellis - a system of growing grapevines for early and high production. Am. J. Enol. Vitic. 35, 82-87.

WEISS, A. \& ALLEN, L., 1976a. Air-flow patterns in vineyard rows. Agric. Meteorol. 16, 329-342.

WEISS, A. \& ALLEN, L., 1976b. Vertical and horizontal air flow above rows of a vineyard. Agric. Meteorol. 17, 433-452. 